\title{
REVIEW \\ JURNAL
}

\begin{tabular}{|c|l|}
\hline Judul & $\begin{array}{l}\text { MENINGKATKAN DAYA SAING PABRIK GULA DI INDONESIA } \\
\text { ERA MASYARAKAT EKONOMI ASEAN }\end{array}$ \\
\hline Jurnal & Jurnal Riset Ekonomi dan Manajemen \\
\hline Vol. \& Hal. & Volume 16, Halaman 225-236 \\
\hline Tahun & 2018 \\
\hline Penulis & Ahmad Zafrullah Tayibnapis, Lucia E. Wuryaningsih, Hj.Made Siti Sundari. \\
\hline Tanggal & 24 Februari 2019 \\
\hline $\begin{array}{c}\text { Referensi } \\
\text { Jurnal }\end{array}$ & $\begin{array}{l}\text { Tayibnapis, A.Z., et al (2018). Meningkatkan daya saing pabrik gula di } \\
\text { Indonesia era masyarakat ekonomi ASEAN, Jurnal Riset Ekonomi dan } \\
\text { Manajemen, 16(2), 225-236 }\end{array}$ \\
\hline Reviewer & Ivan K (130217011) \\
\hline
\end{tabular}

\begin{tabular}{|c|c|}
\hline Abstrak & $\begin{array}{l}\text { Tayibnapis, A.Z., et al (2018) mengemukakan bahwa di Indonesia, Industri } \\
\text { gula memiliki permasalahan mengenai biaya produksi yang tidak ekonomis } \\
\text { karena adanya inefisiensi pada proses produksi. Selain itu ada permasalahan } \\
\text { lain mengenai regulasi dan conflict of interest yang terjadi antara agen } \\
\text { pemerintah dan internal industri yang kerap terjadi karena adanya } \\
\text { ketidakharmonisan antara petani tebu dan pihak industri. Oleh karena itu, } \\
\text { Tayibnapis, A.Z., et al (2018) menyimpulkan bahwa di dalam era masyarakat } \\
\text { ekonomi ASEAN, efisiensi industri gula perlu diperhatikan agar mampu } \\
\text { bersaing dan meningkatkan kesejahteraan baik industri maupun petani. }\end{array}$ \\
\hline Pendahuluan & $\begin{array}{l}\text { Tayibnapis, A.Z., et al (2018) mengungkapkan berbagai hal mendasar } \\
\text { mengenai sejarah pabrik gula dan keterikatan secara ekonomi maupun sosial } \\
\text { dengan masyarakat di Indonesia sejak jaman Belanda. Selain itu, Tayibnapis, } \\
\text { A.Z., et al (2018) juga memaparkan bahwa saat ini, produksi maksimal } \\
\text { belum bisa mencapai target swasembada gula karena terjadinya penurunan } \\
\text { kualitas panen dan rendemen, lemahnya produktivitas, tingginya biaya pokok } \\
\text { produksi GKP, konflik kepentingan antara kementerian, impor rafinasi yang } \\
\text { merembes ke pasar, serta berbagai faktor lainya. Padahal seharusnya, } \\
\text { swasembada gula dapat tercapai karena sebagian pabrik gula sudah dibenahi } \\
\text { dan semakin modern. Namun walau dengan demikian, tetaplah tidak mudah } \\
\text { bagi pabrik gula untuk memperoleh margin karena pendapatan dalam satu } \\
\text { musim giling cukup untuk memenuhi biaya-biaya yang ada. Jadi tidak heran } \\
\text { bila banyak industri gula yang merugi dan terkekang karena pada dasarnya } \\
\text { bisnis butuh margin usaha untuk melakukan ekspansi dan meningkatkan } \\
\text { kapasitas produksi ke depannya. }\end{array}$ \\
\hline & $\begin{array}{l}\text { Tayibnapis, A.Z., et al (2018) dalam melaksanakan penelitiannya } \\
\text { memaparkan berbagai konsep dasar antara lain: } \\
\text { - Teori bahwa produktivitas dan efisiensi yang merupakan aspek } \\
\text { penting dalam kinerja oleh Sink dan Thomas (1989) dalam } \\
\text { Triwulandari S. Dewayana, dkk. (2011) } \\
\text { - Gagasan bahwa keunggulan bersaing suatu organisasi didukung oleh } \\
\text { kemampuan sumber daya dan aktivitas rutin dalam pabrik oleh Craig } \\
\text { dan Grant (2002) dalam Triwulandari S. Dewayana, dkk. (2011) }\end{array}$ \\
\hline
\end{tabular}




\begin{tabular}{|c|c|}
\hline & $\begin{array}{l}\text { - Paparan mengenai optimasi dan pengolahan ampas tebu yang } \\
\text { merupakan sumber energi yang terbarukan oleh (Hugot, 1986; } \\
\text { Paturao, 2989; Lamb, } 1977 \text { \& } 1980 \text { dalam Saechu, 2009) } \\
\text { - Pendapat Michael A. Toman dan Barbora Jemelkova (2003) } \\
\text { mengenai keterkaitan antara energi dan pembangunan ekonomi. } \\
\text { - Pendapat Paul L. Joskow dan Robert W. Fri (2003) mengenai } \\
\text { pembangunan ekonomi berkelanjutan yang membutuhkan kebijakan } \\
\text { energi alternatif agar tidak tergantung pada energi fosil. } \\
\text { - Pemikiran Alfred Marshall (1954) yang telah dikembangkan dalam } \\
\text { Todaro (2011) mengenai kemungkinan bahwa perusahaan dapat } \\
\text { mencapai keseimbangan tertinggi melalui usaha dengan beberapa } \\
\text { cara. } \\
\text { Secara keseluruhan penulis telah menggunakan beberapa sumber yang dapat } \\
\text { menopang dan berkaitan dengan penelitian yang dilakukan sehingga } \\
\text { terbentuk sinergi dan proses penelitian dapat berjalan dengan baik. }\end{array}$ \\
\hline $\begin{array}{c}\text { Metode } \\
\text { penelitian }\end{array}$ & $\begin{array}{l}\text { Penelitian yang dilaksanakan oleh Tayibnapis, A.Z., et al (2018) berjenis } \\
\text { kualitatif karena menyelidiki dan memahami mengenai isu-isu yang ada } \\
\text { dalam industri Gula di tanah air. Penelitian ini menggunakan metode } \\
\text { langsung dan tidak langsung. Metode langsung dilaksanakan dengan } \\
\text { wawancara dan observasi ke pabrik gula dan PTPN X serta pemilik } \\
\text { perkebunan tebu dalam rangka memperoleh kondisi riil yang berjalan di } \\
\text { pabrik gula saat ini. Metode tidak langsung diperoleh dari kajian pustaka, } \\
\text { pengolahan dan analisis data, jurnal dan seminar. Penulis telah berhasil } \\
\text { memaparkan metode penelitian dengan baik dan jelas serta dapat } \\
\text { dipertanggung jawabkan. }\end{array}$ \\
\hline $\begin{array}{c}\text { Temuan } \\
\text { Penelitian }\end{array}$ & $\begin{array}{l}\text { Tayibnapis, A.Z., et al (2018) dalam penelitiannya telah berhasil menemukan } \\
\text { hal-hal yang menjadi hambatan dalam industri gula di tanah air seperti : } \\
\text { - Mafia Bisnis } \\
\text { - Regulasi Pemerintah yang tidak sinergis } \\
\text { - Ketidakharmonisan petani dan industri } \\
\text { - Inefisiensi dalam produksi baik on-farm maupun out-farm yang tidak } \\
\text { ekonomis dan kalah dibandingkan dengan negara-negara lain } \\
\text { Oleh karena itu berdasar dengan hasil penelitian ini, Tayibnapis, A.Z., et al } \\
\text { (2018) mengemukakan gagasan untuk mengembangkan pabrik gula di } \\
\text { Indonesia agar mampu bersaing di ASEAN dan berjalan dengan baik. } \\
\text { Gagasan tersebut adalah : } \\
\text { - Peningkatan mutu sumber daya manusia yang berorientasi kepada } \\
\text { kualitas sumber daya manusia yang terampil, profesional, produktif, } \\
\text { inovatif dan bertalenta. Penulis beranggapan bahwa sumber daya } \\
\text { manusia yang baik akan memajukan perusahaan dengan baik pula. } \\
\text { Tentunya tidak lupa perusahaan juga harus melaksanakan manajemen } \\
\text { talenta yang baik. } \\
\text { Penerapan sistem enterprise resource planning yang baik untuk } \\
\text { membantu efisiensi dalam produktivitas dengan manajemen yang } \\
\text { lebih terstruktur. } \\
\text { Menjalankan diversifikasi produk turunan tebu terutama bahan bakar } \\
\text { alternatif agar mendapatkan pemasukan tambahan dan salah satu cara } \\
\text { untuk memperkecil risiko usaha. }\end{array}$ \\
\hline
\end{tabular}




\begin{tabular}{|c|c|}
\hline & $\begin{array}{l}\text { Berdasar dengan pemaparan hasil penelitian dan hal-hal yang disimpulkan } \\
\text { penulis, bisa dikatakan bahwa penulis cukup optimistis terhadap kemajuan } \\
\text { industri gula di Indonesia pada era MEA bisa menjalankan praktiknya secara } \\
\text { baik dan pembenahan-pembenahan yang akan meningkatkan baik efisiensi }\end{array}$ \\
\hline Kesimpulan & $\begin{array}{l}\text { Tayibnapis, A.Z., et al (2018) memaparkan bahwa pembangunan industri } \\
\text { tebu di Indonesia masih belum terwujud dengan baik karena aneka } \\
\text { permasalahan mendasar, seperti biaya operasional, kualitas rendaman, } \\
\text { inefisiensi produksi, impor gula berlebihan yang membanjiri pasar, dll. Selain } \\
\text { itu pengembangan industri tepu ke depannya menuju swasembada gula dan } \\
\text { beyond sugar masih juga dibayangi dengan konflik kepentingan dan } \\
\text { ketidakharmonisan antara petani dan industri. Penulis juga telah memberikan } \\
\text { saran agar pemerintah menerapkan kebijakan batas impor gula agar industri } \\
\text { dalam negeri dapat lebih berkembang dan maju. Kebijakan pemerintah saat } \\
\text { ini dinilai kurang mendukung dan justru malah memanjakan pabrik gula } \\
\text { rafinasi yang justru menjadi iklim bisnis yang kurang baik sehingga } \\
\text { merugikan industri tebu dalam negeri karena oversupply. Selain itu penulis } \\
\text { juga menyarankan untuk melakukan konversi lahan yang kurang produktif } \\
\text { menjadi lahan tebu sehingga kapasitan dapat ditingkatkan. Tidak lupa pula } \\
\text { penulis juga menyarankan agar melakukan efisiensi dan quality improvement } \\
\text { dalam industri tebu di tanah air. }\end{array}$ \\
\hline Kelebihan & $\begin{array}{l}\text { 1. Penulis mampu memaparkan dengan baik keadaan industri gula tebu } \\
\text { tanah air dan permasalahannya } \\
\text { 2. Penulisan dilaksanakan dengan sistematis dan teratur sehingga mudah } \\
\text { dipahami bagi pembaca awam } \\
\text { 3. Seluruh data dan informasi yang ada sangat informatif dan saling } \\
\text { mendukung. }\end{array}$ \\
\hline Kekurangan & $\begin{array}{l}\text { 1. Ada beberapa bagian yang repetitif yang sebaiknya bisa } \\
\text { disederhanakan sehingga lebih singkat, padat, dan jelas. } \\
\text { Misal : Masalah dasar industri gula yang selalu muncul dari } \\
\text { pendahuluan hingga hasil penelitian }\end{array}$ \\
\hline
\end{tabular}

